\title{
Seabird use of discards and incidental captures at the Argentine hake trawl fishery in the Golfo San Jorge, Argentina
}

\author{
Diego González-Zevallos ${ }^{1}$, Pablo Yorio ${ }^{2, *}$ \\ ${ }^{1}$ Universidad Nacional de la Patagonia, Bv. Brown 3700, 9120 Puerto Madryn, Chubut, Argentina \\ ${ }^{2}$ Centro Nacional Patagónico (CONICET) and Wildlife Conservation Society, Bv. Brown 3500, 9120 Puerto Madryn, \\ Chubut, Argentina
}

\begin{abstract}
We studied discard use and incidental mortality of seabirds attracted to high-sea trawl vessels operating in the Golfo San Jorge, Argentina, during the height of the fishing season in 2003 and 2004. Fourteen seabird species ate food made available by fishing operations. The most frequent and abundant seabirds (percent occurrence, mean number per haul) were the kelp gull Larus dominicanus $(98.9 \%, 207.0)$, the black-browed albatross Thalassarche melanophrys $(98.9 \%, 94.2)$ and the white-chinned petrel Procellaria aequinoctialis $(91 \%, 8.4)$. Flock sizes for the 3 species varied from a few to a maximum of 1600 birds. Total seabird abundance varied significantly between stages of the fishing operation, being higher during discarding and haulback than during towing. Incidental capture of seabirds in nets was recorded in $37 \%$ of 89 hauls, with a mean capture rate of 1.2 birds per haul. Species incidentally caught were the great shearwater Puffinus gravis, the imperial cormorant Phalacrocorax atriceps and the Magellanic penguin Spheniscus magellanicus, with rates that varied between months and years. Considering the fishery's fishing effort, the estimated total numbers of birds killed during the study were 2254 great shearwaters (CV = 1.1), 1233 imperial cormorants $(\mathrm{CV}=1.1)$ and 35 Magellanic penguins $(\mathrm{CV}=2.4)$ in 2003, and 311 imperial cormorants $(\mathrm{CV}=1.7)$ and 1516 Magellanic penguins $(\mathrm{CV}=1.1)$ in 2004. Black-browed albatrosses and kelp gulls were also struck by the warp cable while feeding on discards from the surface, and drowned when they were dragged underwater. The results obtained in this study show that the hake trawl fishery operating in the Golfo San Jorge may have a significant effect on some seabird populations through the provision of fishing discards and incidental mortality.
\end{abstract}

KEY WORDS: Seabird-fishery interactions · Discards · Incidental mortality · Trawl fisheries Resale or republication not permitted without written consent of the publisher

\section{INTRODUCTION}

Seabird foraging distributions frequently overlap with commercial fisheries in high productivity areas around the world. Seabird populations may be both negatively and positively affected by fishery activities (Duffy \& Schneider 1994, Montevecchi 2002). Many seabirds make intensive use of fishery discards, which are a result of the low selectivity of some fishing gears (Tasker et al. 2000). This fish waste constitutes a food source that is abundant and relatively predictable, and includes prey which are not normally available, or which cannot be obtained by usual feeding methods (Furness \& Monaghan 1987). It has been argued that the use of discards has contributed to the expansion of several seabird populations (Furness 2003). The use of fishing waste may increase breeding success, affect community composition and induce changes in the distribution of birds at sea (Wahl \& Heinemann 1979, Ryan \& Moloney 1988, Hudson \& Furness 1989, Oro et al. 1995). Seabird use of fishery waste has been described in several regions, including the North Sea (Furness et al. 1992, Garthe \& Hüppop 1994), Mediterranean Sea (Oro \& Ruiz 1997), NW Atlantic (Chapde- 
laine \& Rail 1997), Pacific Ocean (Jones \& DeGange 1988), Australia and New Zealand (Blaber \& Wassenberg 1989, Petyt 1995), South Africa (Ryan \& Moloney 1988) and the SW Atlantic (Thompson \& Riddy 1995, Yorio \& Caille 1999, Bertellotti \& Yorio 2000).

In addition, seabird attraction to fishing vessels to make use of waste has led in many cases to an increase in mortality resulting from drowning in fishing gear. Several studies have reported high incidental mortality rates at, for example, gill nets, drift nets and longlines (Jones \& DeGange 1988, Brothers 1991, Weimerskirch et al. 1997). On the other hand, little is known about the extent of seabird mortality at trawling vessels, which may occur while birds attempt to obtain food from the net or is due to their collision with vessels or fishing gear cables (Bartle 1991, Weimerskirch et al. 2000, Baird \& Thompson 2002, Sullivan 2004). Given the life-history traits of seabirds, incidental mortality of adult individuals may significantly affect their populations. Seabirds are long lived, have delayed maturity and exhibit low fecundity and high adult survival (Furness \& Monaghan 1987). Thus, seabirds are highly sensitive to slight changes in adult mortality.

More than 50 seabird species forage on the Argentine continental shelf (Canevari et al. 1991), 16 of these also reproduce along the Patagonian coast (Yorio et al. 1998b). Knowledge of seabird-fishery interactions on the Argentine continental shelf is still relatively poor. Discard use by seabirds has been quantitatively analysed only in coastal fisheries (Yorio \& Caille 1999, Bertellotti \& Yorio 2000). Seabird use of fishery waste provided by high-sea trawl fisheries, however, has not yet been analysed, although these fishing fleets have a greater potential of affecting seabird populations due to the larger number of vessels and higher discarding rates. In the present paper we have evaluated the seabird use of discards provided by the high-sea trawl fishery that operates in the Golfo San Jorge, Argentina. We have determined the species composition of seabirds attending vessels, quantified their relative abundance in relation to the fishing season and stages of fishing operations, described their foraging behaviour and quantified mortality as a result of incidental capture of birds attracted to the vessels to make use of fishery waste.

\section{MATERIALS AND METHODS}

Study area and characteristics of coastal fisheries. The Golfo San Jorge (Fig. 1) is one of the most important coastal areas in terms of marine biodiversity and one of the priority seabird areas in Argentina. Of the 16 seabird species breeding in Patagonia, 13 nest on islands of this coastal sector, including a significant proportion of the total population of some of these species (Yorio et al. 1998b). This area is subject to several human activities, including commercial fisheries. About 20 ice trawlers operate from September to May, generally from 20 to $50 \mathrm{~km}$ offshore, although they occasionally fish in waters outside the Golfo San Jorge, to distances $>100 \mathrm{~km}$ offshore. These vessels are $26.4 \pm 2.4 \mathrm{~m}$ long (range $=21.2$ to 30.9 ), have $458.1 \pm 65.0 \mathrm{HP}$ (range $=380$ to 624$)$ and tow bottom nets (100 to $120 \mathrm{~mm}$ mesh size; 2 and $20 \mathrm{~m}$ vertical and horizontal mouth openings, respectively) at 3 knots. Trawls last between 2 and $3 \mathrm{~h}$. The target species is the Argentine hake Merluccius hubbsi. Trips by trawlers last between 1 and $5 \mathrm{~d}$ ( 5 to 7 hauls d ${ }^{-1}$ ). Fish are sorted on deck, and non-commercial sizes of hake and bycatch species are discarded overboard. An average of 1.5 tons of fishery waste was produced per haul by the hake fisheries during the study period in 2004, and total biomass discarded during this period by all vessels operating in the area was estimated at 4200 tons (D. González-Zevallos \& P. Yorio unpubl. data). No offal is discarded at sea.

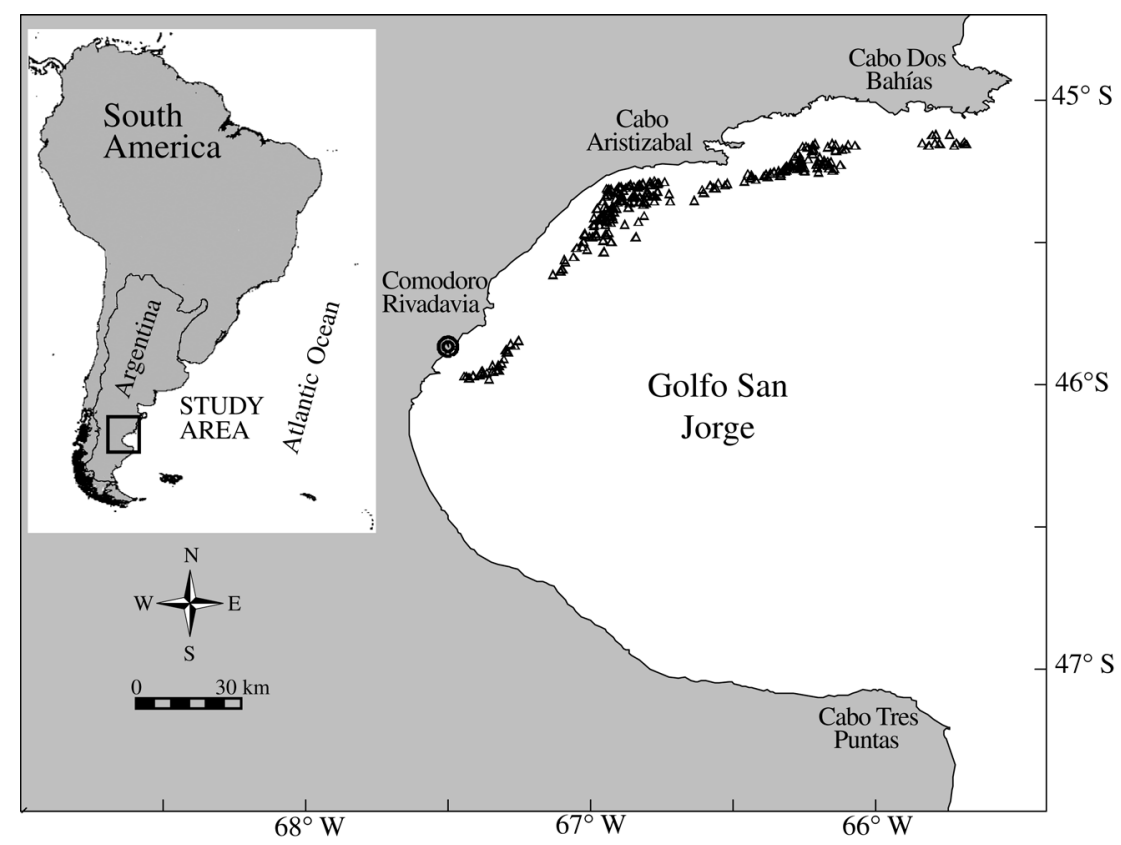

Fig. 1. Map of the Golfo San Jorge, Argentina, showing the spatial distribution of the trawl fishery ( $\Delta$ : location of hauls) 
In addition to the ice trawlers, the waters of the Golfo San Jorge are used by about 70 freezer trawlers targeting Argentine red shrimp Pleoticus muelleri and a few small coastal trawlers also fishing for Argentine hake.

Species and abundance of seabirds associated with fishing vessels. Information was gathered on board 5 different ice trawlers (25\% of the fishing fleet size), for a total of 89 hauls (26 fishing days) from January to March 2003 and during January and March 2004. Fishing operations were divided into 3 activities: (1) haulback, lifting of the net to the vessel; (2) discarding, sorting and discarding of fish while towing the net; and (3) towing of the net after fish on board have been classified and discards are no longer available. During all trips and for each fishing activity, seabirds associated with the vessel were identified to species level, and several counts were made during each haul, totalling 241 counts (81 during 'haulback', 76 during 'discarding' and 84 during 'towing'). Mean numbers of each species were recorded for each haul. Frequency of occurrence was defined as the percentage of hauls in which each species was observed.

Seabird behaviour and incidental captures in nets. Observations on feeding behaviour, including foraging methods (following Ashmole 1971), and interactions between species and between birds and fishing gear were made on an opportunistic basis. Information on the incidental capture of seabirds was also obtained at each haul, recording species identity, number of birds caught and whether the bird survived. In addition, for each haul, the number of fishing vessels operating within sight was recorded.

Statistical analysis. Results concerning seabird use of discards were analysed using non-parametric statistics, since data on counts often presented positively skewed distributions. Contrasts were performed using the Z-test for non-parametric multiple comparisons. Comparisons of numbers of seabirds associated with the vessel during different stages of the fishing operation were made using Friedman's 2-way analysis of variance. Results are given as mean numbers and ranges of individuals (min., max.). The estimated number of birds killed was calculated after adapting the methods described by Klaer \& Polacheck (1995) for longliners to trawlers:

$$
\hat{B}=H \frac{\sum_{i=1}^{c} H_{i} \bar{b}_{i}}{\sum_{i=1}^{c} H_{i}}
$$

where $\hat{B}$ represents the estimated total birds caught, $b$ is the observed number of birds caught, $H$ is the total number of hauls, $h$ is the number of observed hauls, $\bar{b}_{i}=\frac{b_{i}}{h_{i}}$ is the mean number of observed birds caught per haul in cruise $i, i$ is the cruise number and $c$ is the number of observed cruises.

Coefficients of variation (CV), expressed as a direct ratio of standard deviation/mean (Zar 1999), are given for estimates because these are more useful than confidence intervals for comparing relative precision.

\section{RESULTS}

\section{Species and abundance of seabirds associated with fishing vessels}

A total of 14 seabird species were recorded eating food made available by the hake trawl fishery operating in the Golfo San Jorge (Table 1). The most frequent seabirds were the kelp gull Larus dominicanus, the black-browed albatross Thalassarche melanophrys

Table 1. Frequency of occurrence (\%) and mean numbers (range in parentheses) per haul of seabirds attending highsea trawlers in the Golfo San Jorge during the fishing seasons of 2003 and 2004

\begin{tabular}{|c|c|c|}
\hline Species & $\begin{array}{l}\text { Frequency of } \\
\text { occurrence }\end{array}$ & Mean \\
\hline $\begin{array}{l}\text { Kelp gull } \\
\quad \text { Larus dominicanus }\end{array}$ & 98.9 & $207.0(0-1600)$ \\
\hline $\begin{array}{l}\text { Black-browed albatross } \\
\text { Thalassarche melanophrys }\end{array}$ & 98.9 & $94.2(0-600)$ \\
\hline $\begin{array}{l}\text { White-chinned petrel } \\
\text { Procellaria aequinoctialis }\end{array}$ & 91.0 & $8.4(0-100)$ \\
\hline $\begin{array}{l}\text { Great shearwater } \\
\text { Puffinus gravis }\end{array}$ & 88.8 & $38.2(0-800)$ \\
\hline $\begin{array}{l}\text { Southern giant petrel } \\
\text { Macronectes giganteus }{ }^{\mathrm{a}}\end{array}$ & 83.1 & $1.6(0-15)$ \\
\hline $\begin{array}{l}\text { Imperial cormorant } \\
\text { Phalacrocorax atriceps }{ }^{\mathrm{a}}\end{array}$ & 77.5 & $19.1(0-200)$ \\
\hline $\begin{array}{l}\text { Sooty shearwater } \\
\text { Puffinus griseus }\end{array}$ & 50.6 & $2.7(0-100)$ \\
\hline $\begin{array}{l}\text { Magellanic penguin } \\
\text { Spheniscus magellanicus }\end{array}$ & 49.4 & $8.2(0-200)$ \\
\hline $\begin{array}{l}\text { Antarctic skua } \\
\quad \text { Catharacta antarctica }{ }^{a}\end{array}$ & 47.2 & $0.4(0-8)$ \\
\hline $\begin{array}{l}\text { South American tern } \\
\text { Sterna hirundinacea }\end{array}$ & 39.3 & $1.7(0-40)$ \\
\hline $\begin{array}{l}\text { Wilson's storm-petrel } \\
\text { Oceanites oceanicus }\end{array}$ & 18.0 & $0.6(0-12)$ \\
\hline $\begin{array}{l}\text { Cayenne tern } \\
\text { Sterna eurygnatha }{ }^{\mathrm{a}}\end{array}$ & 13.5 & $1.1(0-45)$ \\
\hline $\begin{array}{l}\text { Royal albatross } \\
\text { Diomedea epomophora }\end{array}$ & 9.0 & $0.04(0-1)$ \\
\hline $\begin{array}{l}\text { Sheathbill } \\
\quad \text { Chionis alba }\end{array}$ & 2.2 & $0.01(0-1)$ \\
\hline \multirow{2}{*}{\multicolumn{2}{|c|}{$\begin{array}{l}\text { Mean number of species per haul } \\
\text { Mean number of birds per haul }\end{array}$}} & $5.9(0-10)$ \\
\hline & & $383.3(0-2012)$ \\
\hline
\end{tabular}


Table 2. Mean number (range in parentheses) of individuals per haul for the 6 most frequent seabirds attending high-sea trawlers at Golfo San Jorge during different months of the fishing season of 2003 ( $\mathrm{n}=50$ hauls) and 2004 ( $\mathrm{n}=39$ hauls)

\begin{tabular}{|c|c|c|c|c|c|}
\hline Species & Jan & Feb & Mar & \multicolumn{2}{|c|}{ Kruskal-Wallis } \\
\hline 2003 & $(\mathrm{n}=7)$ & $(\mathrm{n}=11)$ & $(\mathrm{n}=32)$ & $H$ & $\mathrm{p}$ \\
\hline Kelp gull & $231.0(16-500)$ & $137.0(0-400)$ & $83.3(0-800)$ & 25.5 & $<0.001$ \\
\hline Black-browed albatross & $120.2(10-300)$ & $47.8(0-150)$ & $73.4(0-600)$ & 8.9 & 0.011 \\
\hline White-chinned petrel & $42.4(7-100)$ & $1.9(0-25)$ & $7.6(0-50)$ & 58.8 & $<0.001$ \\
\hline Great shearwater & $0.6(0-3)$ & $8.2(0-50)$ & $83.3(0-800)$ & 76.5 & $<0.001$ \\
\hline Southern giant petrel & $1.5(0-4)$ & $3.2(0-11)$ & $1.0(0-9)$ & 18.6 & $<0.001$ \\
\hline Imperial cormorant & $0.05(0-1)$ & $13.6(0-70)$ & $13.7(0-200)$ & 19.6 & $<0.001$ \\
\hline & & & & \multicolumn{2}{|c|}{ Mann-Whitney } \\
\hline 2004 & $(\mathrm{n}=19)$ & $(-)$ & $(\mathrm{n}=20)$ & $U$ & $\mathrm{p}$ \\
\hline Kelp gull & $428.7(10-1500)$ & - & $252.3(0-1600)$ & 854.5 & 0.007 \\
\hline Black-browed albatross & $186.7(0-500)$ & - & $58.7(0-350)$ & 813.5 & 0.003 \\
\hline White-chinned petrel & $2.6(0-12)$ & - & $4.7(0-20)$ & 980.5 & ns \\
\hline Great shearwater & $1.6(0-5)$ & - & $19.5(0-200)$ & 593 & $<0.001$ \\
\hline Southern giant petrel & $3(0-15)$ & - & $0.5(0-5)$ & 669.5 & $<0.001$ \\
\hline Imperial cormorant & $37.6(0-200)$ & - & $22.1(0-200)$ & 895.5 & 0.014 \\
\hline
\end{tabular}

and the white-chinned petrel Procellaria aequinoctialis, followed by the great shearwater Puffinus gravis, southern giant petrel Macronectes giganteus, imperial cormorant Phalacrocorax atriceps and sooty shearwater Puffinus griseus. The most abundant seabirds were the kelp gull and black-browed albatross. The rest of the species were observed in low numbers and in $<50 \%$ of hauls (Table 1 ).

The abundance of the seabirds most frequently associated with the fishery (kelp gull, black-browed albatross, white-chinned petrel, great shearwater, southern giant petrel and imperial cormorant) varied among sampled months during 2003 (Fig. 2). Mean numbers of kelp gulls were highest during January and decreased towards March (Table 2), with flock sizes which varied between 2 and 800 individuals (Fig. 2). Great shearwaters were significantly more abundant in March ( $Z$-test $=14.84 ; \mathrm{p}<0.001)$, when flock sizes reached 800 birds (Fig. 2). Numbers of white-chinned petrels were significantly higher during January (Table 2), reaching a maximum of 100 birds per haul (Fig. 2). Imperial cormorants were almost absent in counts during January, and southern giant petrels were recorded in groups of $<11$ individuals (Fig. 2). The number of blackbrowed albatrosses varied between 1 and 600 individuals (Fig. 2). During 2004, numbers of kelp gulls, black-browed albatrosses, southern giant petrels and imperial cormorants were significantly higher during January, while the great shearwater was more abundant during March (Table 2). Numbers of white- chinned petrels were similar between months (Table 2). Flock sizes for the 3 most abundant species varied between a few and several hundred individuals, with a maximum of 1600 birds in the case of the kelp gull (Fig. 2). Similar to what was observed in 2003, southern giant petrels were recorded in groups of $<15$ individuals (Fig. 2). Mean numbers of kelp gulls and imperial cormorants per haul were significantly higher in 2004 than in 2003, while those for great shearwater and white-chinned petrel were significantly lower in 2004 (Table 3). For the rest of the species, the number of individuals per haul did not differ between years (Table 3).

Total seabird abundance varied significantly between stages of the fishing operation, with total numbers being higher during discarding and haulback than during towing (Table 4). Except for the kelp gull, no significant differences were found in seabird numbers between haulback and discarding (Table 4).

Table 3. Abundances of the 6 most frequent seabird species (mean number and range per haul) during January and March of 2003 and 2004. ns: not significant

\begin{tabular}{|lcccc|}
\hline Species & 2003 & 2004 & \multicolumn{2}{c|}{ Mann-Whitney } \\
& $(\mathrm{n}=50)$ & $(\mathrm{n}=39)$ & $U$ & $\mathrm{p}$ \\
\hline Kelp gull & $114.8(0-800)$ & $337.0(0-1600)$ & 2893.5 & $<0.001$ \\
Black-browed albatross & $75.8(0-600)$ & $120.2(0-500)$ & 5655.5 & $\mathrm{~ns}$ \\
White-chinned petrel & $11.8(0-100)$ & $3.7(0-20)$ & 3609 & $<0.001$ \\
Great shearwater & $57.6(0-800)$ & $10.9(0-200)$ & 2479.5 & $<0.001$ \\
Southern giant petrel & $1.5(0-11)$ & $1.74(0-15)$ & 5551.5 & $\mathrm{~ns}$ \\
Imperial cormorant & $11.6(0-200)$ & $29.5(0-200)$ & $3422.5<0.001$ \\
\hline
\end{tabular}



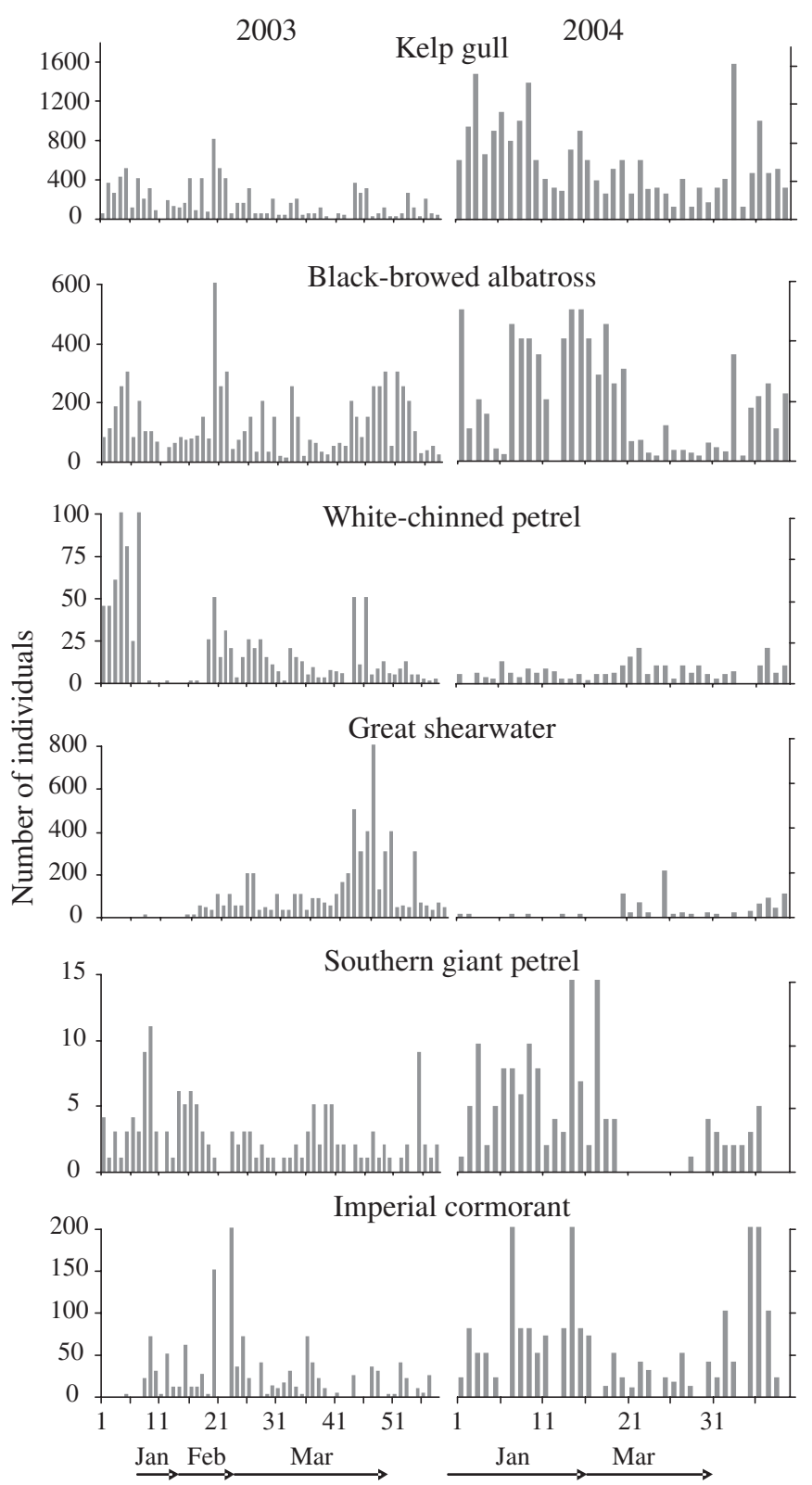

Number of hauls

Fig. 2. Flock sizes of the 6 most abundant seabird species associated with hake trawl vessels in the Golfo San Jorge during the sampled periods in 2003 and 2004

\section{Feeding behaviour}

Seabirds took advantage of food provided by fishing activities at several stages of the fishing operations using different feeding methods (Table 5). Seabirds fed mainly on fish and invertebrates thrown overboard during discarding activities, but they also obtained prey from, or which fell off, the net during haulback, and frequently captured marine organisms brought to the surface by the vessel and net during towing.
In $47 \%$ of hauls $(\mathrm{n}=89)$, between 1 and 5 vessels were operating at about the same time and relatively close to each other (1 to $3 \mathrm{~km}$ ) at the same fishing area. Seabirds were frequently observed coming from other vessels when haulback activities started.

\section{Seabird incidental mortality}

The incidental capture of seabirds in nets was recorded in $37 \%$ of the hauls analysed during the 2 study years ( $\mathrm{n}=89$ hauls). A total of 104 individuals were caught, of which $9.4 \%$ were able to escape alive. Mean capture rate was 1.2 birds per haul ( $\mathrm{n}=89$ hauls). The 96 birds that were killed corresponded to 3 of the 14 species observed in association with fishing vessels: the great shearwater, the imperial cormorant and the Magellanic penguin Spheniscus magellanicus. These 3 species were incidentally caught in nets during haulback, with rates that varied between months and years (Table 6). In general, incidental mortality was higher during the months when the number of associated seabirds was highest (Table 6). For the 3 species, the number of individuals killed differed between years. Incidental mortality of great shearwaters and imperial cormorants was higher in 2003, while more Magellanic penguins were killed in 2004 (Table 6). In 81\% of hauls where incidental mortality was recorded $(\mathrm{n}=$ 32) several individuals of the same species were caught, reaching a maximum number per haul of 10, 7 and 6 individuals for the great shearwater, Magellanic penguin and the imperial cormorant, respectively.

A total of 19 high-sea ice trawlers operated during the study period, with a total of 602 and 455 fishing days in 2003 and 2004, respectively (Secretaría de Pesca de la Provincia de Chubut, Delegación Zona Sur, unpubl. data). Considering that each vessel conducts a minimum of 5 hauls $\mathrm{d}^{-1}$ during the height of the fishing season, an estimated total of 3010 and 2275 hauls were made during 2003 and 2004, respectively. The estimated total number of birds killed for the 3 mo of study in 2003 was $3522(\mathrm{CV}=0.88)$, including 2254 (CV = 1.1) great shearwaters, $1233(\mathrm{CV}=1.1)$ imperial cormorants and $35(\mathrm{CV}=2.4)$ Magellanic penguins. During the 2 mo period in 2004, the total estimated number of birds killed was 1827 (CV = 0.7). This included 1516 $(\mathrm{CV}=1.1)$ Magellanic penguins and $311(\mathrm{CV}=1.7)$ imperial cormorants. It has to be stressed that the estimates presented are just an indication of the actual figures of birds killed.

Black-browed albatross and kelp gull mortality was also recorded during opportunistic observations made at the stern of the vessel during discarding activities. Birds were struck by the warp cable while feeding on discards from the surface, and drowned when they 
Table 4. Mean number (range in parentheses) of individuals per haul during different stages of the fishing operation $(\mathrm{n}=$ 89 hauls) for the 6 most frequent seabird species. Different letters indicate significant differences among different stages of the fishing operation

\begin{tabular}{|c|c|c|c|c|c|}
\hline \multirow[t]{2}{*}{ Species } & \multirow[t]{2}{*}{ Haulback } & \multirow[t]{2}{*}{ Discarding } & \multirow[t]{2}{*}{ Towing } & \multicolumn{2}{|c|}{ Friedman } \\
\hline & & & & $T^{2}$ & $\mathrm{p}$ \\
\hline Kelp gull & $249.1(0-1600)(B)$ & $340.4(0-1500)(\mathrm{C})$ & $45.6(0-300)(\mathrm{A})$ & 43.7 & $<0.001$ \\
\hline Black-browed albatross & $127.6(0-500)(B)$ & $143.3(0-600)(\mathrm{B})$ & $17.6(0-60)(\mathrm{A})$ & 51 & $<0.001$ \\
\hline White-chinned petrel & $9.9(0-100)(\mathrm{B})$ & $12.2(0-100)(\mathrm{B})$ & $3.6(0-20)(\mathrm{A})$ & 9.5 & $<0.001$ \\
\hline Great shearwater & $54.4(0-500)(\mathrm{B})$ & $43.9(0-800)(\mathrm{B})$ & $10.8(0-40)(\mathrm{A})$ & 5.5 & 0.005 \\
\hline Southern giant petrel & $2.9(0-15)(\mathrm{B})$ & $1.3(0-11)(\mathrm{B})$ & $0.6(0-10)(\mathrm{A})$ & 17.9 & $<0.001$ \\
\hline Imperial cormorant & $32.2(0-200)(B)$ & $16.9(0-200)(B)$ & $8.4(0-90)(\mathrm{A})$ & 5.2 & 0.006 \\
\hline Total no. of individuals (14 species) & $498.6(0-2012)(B)$ & $576.7(0-957)(\mathrm{B})$ & $97.2(0-360)(\mathrm{A})$ & 49.1 & $<0.001$ \\
\hline
\end{tabular}

Table 5. Feeding methods (based on Ashmole 1971) used by seabirds associated with high-sea trawlers in the Golfo San Jorge during the fishing seasons of 2003 and 2004 ( $n=89$ hauls)

\begin{tabular}{|c|c|}
\hline Species & Feeding method \\
\hline Kelp gull & $\begin{array}{l}\text { Surface plunging, surface-seizing } \\
\text { and intra and interspecific } \\
\text { kleptoparasitism }\end{array}$ \\
\hline Black-browed albatross & $\begin{array}{l}\text { Surface-seizing, diving (up to } 2 \text { or } \\
3 \mathrm{~m} \text { depth), and intra- and inter- } \\
\text { specific kleptoparasitism }\end{array}$ \\
\hline Great shearwater & $\begin{array}{l}\text { Surface-seizing, diving } \\
\text { (to }>5 \mathrm{~m} \text { depth) }\end{array}$ \\
\hline White-chinned petrel & $\begin{array}{l}\text { Surface-seizing, diving } \\
\text { (to }>5 \mathrm{~m} \text { depth) }\end{array}$ \\
\hline Southern giant petrel & $\begin{array}{l}\text { Surface-seizing, scavenging and } \\
\text { preyed upon other seabirds } \\
\text { associated with the vessel }\end{array}$ \\
\hline Imperial cormorant & Pursuit diving \\
\hline Magellanic penguin & Pursuit diving \\
\hline Sooty shearwater & $\begin{array}{l}\text { Surface-seizing, diving } \\
\text { (to }>5 \mathrm{~m} \text { depth) }\end{array}$ \\
\hline Antarctic skua & Aerial kleptoparasitism \\
\hline South American tern & Plunge-diving \\
\hline Wilson's storm-petrel & Pattering \\
\hline Cayenne tern & Plunge-diving \\
\hline Royal albatross & Surface-seizing \\
\hline Sheathbill & $\begin{array}{l}\text { Landed on the vessel and took } \\
\text { fish left after the catch was sorted }\end{array}$ \\
\hline
\end{tabular}

were dragged underwater. During 32 hauls in March 2003, 3 black-browed albatrosses were killed, resulting in an estimated mortality of at least 111 individuals during that month. No gulls were killed in 2003. Two cases of black-browed albatross mortality were recorded in a total of 39 hauls during January and March 2004, and thus at least 117 individuals could have been killed during those months. A total of $3 \mathrm{kelp}$ gulls were killed by cables during 2004, resulting in an estimated mortality of at least 175 gulls during the study period in that year.
Table 6. Incidental capture and estimated mortality for great shearwaters Puffinus gravis, imperial cormorants Phalacrocorax atriceps and Magellanic penguins Spheniscus magellanicus during the study period ( $\mathrm{n}=89$ hauls)

\begin{tabular}{|c|c|c|c|c|c|}
\hline & \multicolumn{3}{|c|}{2003} & \multicolumn{2}{|c|}{2004} \\
\hline & Jan & Feb & Mar & Jan & Mar \\
\hline $\begin{array}{l}\text { Total estimated hauls } \\
\text { for the whole fishery }\end{array}$ & 780 & 1040 & 1190 & 1070 & 1205 \\
\hline Sampled hauls & 7 & 11 & 32 & 19 & 20 \\
\hline \multicolumn{6}{|l|}{ Great shearwater } \\
\hline Flock size & $2-3$ & $2-50$ & $2-800$ & $2-5$ & $2-200$ \\
\hline No. of individuals killed & 0 & 0 & 42 & 0 & 0 \\
\hline Mortality rate (ind. haul ${ }^{-1}$ ) & - & - & 1.31 & - & - \\
\hline Estimated total mortality & & 2254 & & & 0 \\
\hline \multicolumn{6}{|l|}{ Imperial cormorant } \\
\hline Flock size & 1 & $2-70$ & $2-200$ & $2-200$ & $2-200$ \\
\hline No. of individuals killed & 0 & 0 & 23 & 0 & 5 \\
\hline Mortality rate (ind. haul ${ }^{-1}$ ) & - & - & 0.72 & - & 0.25 \\
\hline Estimated total mortality & & 1233 & & & 11 \\
\hline \multicolumn{6}{|l|}{ Magellanic penguin } \\
\hline Flock size & 2 & $2-24$ & $2-6$ & $4-200$ & $2-3$ \\
\hline No. of individuals killed & 0 & 1 & 0 & 25 & 0 \\
\hline Mortality rate (ind. haul ${ }^{-1}$ ) & - & 0.09 & - & 1.31 & - \\
\hline Estimated total mortality & & 35 & & & 516 \\
\hline
\end{tabular}

\section{DISCUSSION}

Fourteen seabird species ate fishery waste provided by the high-sea trawl fishery operating in the Golfo San Jorge. Of the 14 species reported here, 13 had been previously observed attending coastal fisheries in the Golfo San Jorge (8 species) or elsewhere in Patagonia (Yorio \& Caille 1999). However, some species were present in almost all hauls, while others were recorded infrequently and at very low numbers. As was observed in Patagonian coastal fisheries (Yorio \& Caille 1999, Bertellotti \& Yorio 2000), the kelp gull and the black-browed albatross were the 2 most frequent and abundant species at trawlers. These 2 seabirds regularly associate with fishing vessels throughout their hemispheric distribution, showing their ability to 
take advantage of food made available by fisheries throughout their range and the importance of discards for their populations (Fordham 1970, Abrams 1983, Petyt 1995, Thompson \& Riddy 1995, Branco 2001, Weichler et al. 2004).

As expected, seabird abundances were higher during haulback and discarding (i.e. when the most food was available). Similar results were found in studies of trawlers operating in the Golfo San Matías, Argentina, and in other regions (e.g. Bertellotti \& Yorio 2000, Arcos \& Oro 2002). The variability in the number of seabirds in relation to the different fishing activities also suggests that seabirds move among vessels operating in the same fishing area, taking advantage of the food resources when they were more available. During most hauls (47\%), between 1 and 5 vessels were operating at about the same time and relatively close to each other (within $3 \mathrm{~km}$ radius).

Argentine hake Merluccius hubbsi constitutes $>90 \%$ percent of the catch in the high-sea trawl fisheries operating in the Golfo San Jorge (D. González-Zevallos \& P. Yorio unpubl. data). Although discard composition was not quantified, this suggests that a significant fraction of fishery waste consists of individual Argentine hake below commercial size (which is $30 \mathrm{~cm}$ long). Argentine hake discarded at the high-sea trawl fishery in the Golfo San Jorge was taken by most seabirds. It should be noted that Argentine hake is a demersal species that is not normally available to seabirds that surface-feed. Thus, the high-sea trawl fishery provides seabirds feeding at the Golfo San Jorge with several thousand tons of food per year, a highly abundant and predictable food source that would not be accessible if it were not for fishery activities. Given that seabirds only consume a fraction of the total fish biomass discarded due to the differential selection of species and sizes of discarded fish (e.g. Hudson \& Furness 1989, Camphuysen 1994, Bertellotti \& Yorio 2000), future studies should focus on the evaluation of prey preferences and percentage of discards consumed by different seabirds, to better understand the contribution of this supplementary food source to seabird populations.

Several authors have suggested that the use of fishery waste by some seabirds has contributed to their population growth (Furness 2003). Of the seabirds that nest in Patagonia and that took advantage of discards, the kelp gull is the most abundant and widely distributed species (Yorio et al. 1998b). Kelp gulls in Patagonia are feeding generalists (Bertellotti \& Yorio 1999), and usually take advantage of fishery waste at sea (Yorio \& Caille 1999, Bertellotti \& Yorio 2000). Because fish is valuable in energy and nutritional terms (Pierotti \& Annett 1991, Bolton et al. 1992, Annett \& Pierotti 1999), the consumption of waste fish is probably advantageous for kelp gull breeding success and sur- vival, particularly for young individuals. Many kelp gull colonies have increased in number during the last 2 decades (Yorio et al. 1998a), including those located within the Golfo San Jorge, and it has been suggested that the use of discards and other food sources outside their natural diet (e.g. urban waste and fish waste from processing plants) may be contributing to the observed kelp gull population expansion (Bertellotti \& Yorio 2000, Giaccardi \& Yorio 2004, Yorio \& Caille 2004).

Although discard use may be beneficial for some birds, attraction to vessels to make use of this resource may result in mortality due to interactions with fishing gear (Baird \& Thompson 2002, Baker et al. 2002, Sullivan 2004). Imperial cormorants, Magellanic penguins and great shearwaters were incidentally caught during haulback. These species usually dive to take prey directly from the net during this stage, increasing their chances of becoming entangled. Diving behaviours, thus, make these seabirds more vulnerable to incidental capture in nets. Although black-browed albatrosses were recorded diving a few metres to obtain sinking prey, diving is not their usual feeding method to obtain discards. However, black-browed albatrosses as well as kelp gulls were drowned when their wings were trapped in the cables that hold the net while they were attempting to obtain discards behind the vessel. Blackbrowed albatrosses, as well as many kelp gull individuals, take discards from the surface behind the vessel, increasing the chances of mortality. Cases of incidental mortality due to the birds being dragged under water after being struck by the warp cable have been recently reported for vessels operating in the Malvinas (Falkland) Islands Exclusive Economic Zone (Sullivan \& Reid 2002, Sullivan 2004). The rate of mortality in fishing gear appears to be related to the number of birds associated with the vessel, as, in general, incidental capture of great shearwaters, imperial cormorants and Magellanic penguins occurred during the months when their highest abundances were recorded. In addition, bird densities and high activity during prey obtention at the haulback stage may favour the occurrence of incidental captures (authors' pers. obs.).

Incidental mortality of the 3 species has been previously recorded in fishing vessels operating in the Argentine continental shelf. About 650 Magellanic penguins have been estimated to be killed per summer in the Argentine shrimp fishery also operating in the Golfo San Jorge (Gandini et al. 1999), about 100 individuals $\mathrm{yr}^{-1}$ in the silverside Sorgentinia incisa fishery operating from Puerto Quequén in the southern Buenos Aires Province (Tamini et al. 2002) and 84 individuals during a 19 mo period in Patagonian coastal fisheries (Yorio \& Caille 1999). This study suggests that high-sea trawlers fishing for Argentine hake could have a 
greater impact on Magellanic penguin populations than previously studied fisheries. Imperial cormorant mortality has also been recorded, although in lower frequency, in the Argentine shrimp fishery (Gandini et al. 1999) and in Patagonian coastal fisheries (Yorio \& Caille 1999). Magellanic penguin and imperial cormorant breeding populations in the Golfo San Jorge have been estimated at 463000 and 31000 individuals, respectively (Yorio et al. 1998b), and therefore mortality at hake trawl vessels may be significant for at least imperial cormorants during some years. However, it should be noted that given the uncertainty associated with the mortality estimates, these should only be considered an indication of the actual figures of birds killed.

The black-browed albatross is catalogued as endangered according to UICN criteria (Birdlife-International/ UICN 2001), so the observed mortality is a matter of concern. Black-browed albatross populations have shown a significant reduction in numbers, particularly at the South Georgia, Kerguelen and Malvinas Islands (Robertson \& Gales 1998, Huin 2001), and it has been argued that this is in part a result of the incidental mortality recorded in longline fisheries (Robertson \& Gales 1998). Recent information indicates that the blackbrowed albatross is one of the species most affected by the longline fisheries operating on the Argentine continental shelf (Favero et al. 2003) and by the trawlers operating in the water of the Malvinas Islands (Sullivan 2004). This study shows that $>100$ birds of this species were drowned in each of the studied periods when they were trapped by cables. However, it has to be noted that such mortality is probably underestimated, because no continuous observations were made from the stern of the vessel, and thus some birds caught in the cables could have rapidly disappeared underwater without being seen. In some cases, drowned blackbrowed albatrosses and kelp gulls were recovered when they came in caught in the cable during the next haul (authors' pers. obs.).

The evaluation of incidental capture of seabirds by high-sea trawlers operating on the Argentine continental shelf has mainly been based on records of the direct mortality of seabirds in nets, or through interviews with vessel captains after their return to port (Gandini et al. 1999, Yorio \& Caille 1999, E. Crespo pers. comm.). This study suggests that the estimations of seabird mortality using such methods may be inadequate for some species, as birds killed due to their interactions with fishing gear may be overlooked if continuous observations behind the vessels are not made. Therefore, protocols of high-sea trawl vessels should include the sampling of seabird feeding behaviour behind the vessel, so as to correctly quantify mortality rates of some species associated with discard operations.
The results obtained in this study show that the hake trawl fishery operating in the Golfo San Jorge might have a significant effect on some seabird populations through the provision of fishing waste, particularly for kelp gulls and, probably, black-browed albatrosses. In addition, results show that seabird attraction to fishing vessels to feed on waste fish can increase their mortality due to incidental captures, and may be having an important negative effect on some seabird populations. The total effect on seabird populations feeding in the Golfo San Jorge is probably higher than that observed in this study, as other high-sea fishing fleets operate in the area. Therefore, future research efforts should focus on the evaluation of the interaction between seabirds and high-sea trawlers, in order to obtain a more integrated knowledge on the fishing effects on seabirds feeding in the Golfo San Jorge.

Acknowledgements. We thank the Wildlife Conservation Society and the 'Survey of Marine Birds in the South Atlantic' project, implemented by Fundación Patagonia Natural, for support in conducting this study. Thanks to Centro Nacional Patagónico (CONICET) for institutional support and Secretaría de Pesca de la Provincia del Chubut, Delegación Zona Sur, for logistical support. Special thanks to G. Caille, G. Harris, J. M. Musmeci, M. V. Rodriguez, S. Copello, L. Venerus, B. Sullivan, T. Reid, J. Perez Botel, J. Burella, R. Álvarez, E. Murphy, M. Álvarez and the captains and crews of the hake trawlers for their help and advice, and to an anonymous referee for helping improve the final version.

\section{LITERATURE CITED}

Abrams RW (1983) Pelagic seabirds and trawl-fisheries in the southern Benguela Current region. Mar Ecol Prog Ser 11: $151-156$

Annett C, Pierotti R (1999) Long-term reproductive output in western gulls: consequences of alternate tactics in diet choice. Ecology 80:288-297

Arcos JM, Oro D (2002) Significance of nocturnal purse seine fisheries for seabirds: a case study off the Ebro Delta (NW Mediterranean). Mar Biol 141:277-286

Ashmole NP (1971) Sea bird ecology and the marine environment. In: Farner DS, King JK, Parkes KC (eds) Avian biology. Academic Press, New York, p 223-286

Baird S, Thompson D (2002) Seabirds and the hoki (Macruronus novaezelandiae) trawl fishery: a review of current knowledge. National Institute of Water and Atmospheric Research, Wellington

Baker GB, Gales R, Hamilton S, Wilkinson V (2002) Albatrosses and petrels in Australia: a review of their conservation and management. EMU 102:71-97

Bartle JA (1991) Incidental capture of seabirds in the New Zealand subantarctic squid trawl fishery, 1990. Bird Conserv Int 1:351-359

Bertellotti M, Yorio P (1999) Spatial and temporal patterns in the diet of the kelp gull in northern Chubut, Patagonia. Condor 101:790-798

Bertellotti M, Yorio P (2000) Utilisation of fishery waste by kelp gulls attending coastal trawl and longline vessels in northern Patagonia, Argentina. Ornis Fenn 77:105-115

Birdlife-International/UICN (2001) Threatened birds of the world. Birdlife-International/UICN, Cambridge 
Blaber SJM, Wassenberg TJ (1989) Feeding ecology of the piscivorous birds Phalacrocorax varius, P. melanoleucos and Sterna bergii in Moreton Bay, Australia: diets and dependence on trawler discards. Mar Biol 101:1-10

Bolton M, Houston D, Monaghan P (1992) Nutritional constraints on egg formation in the lesser black-backed gull: an experimental study. J Anim Ecol 61:521-532

Branco JO (2001) Descarte da pesca do camarão sete-barbas como fonte de alimento para aves marinhas. Rev Bras Zool 18:293-300

Brothers N (1991) Albatross mortality and associated bait loss in the Japanese longline fishery in the Southern Ocean. Biol Conserv 55:255-268

Camphuysen CJ (1994) Scavenging seabirds at beam trawlers in the southern North Sea: distribution, relative abundance, behaviour, prey selection, feeding efficiency, kleptoparasitism, and the possible effects of the establishment of 'protected areas'. BEON Report 1994-14, Netherlands Institute for Sea Research, Texel

Canevari M, Canevari P, Carrizo GR, Harris G, Mata JR, Straneck RJ (1991) Nueva guía de las aves argentinas. Fundación Acindar, Buenos Aires

Chapdelaine G, Rail JF (1997) Relationship between cod fishery activities and the population of herring gulls on the north shore of the Gulf of St. Lawrence, Québec, Canada. ICES J Mar Sci 54:708-713

Duffy DC, Schneider DC (1994) Seabird-fishery interactions: a manager's guide. In: Nettleship DN, Burger J, Gochfeld $M$ (eds) Seabirds on islands: threats, case studies and action plans. Birdlife Conservation Series 1, Birdlife International, Cambridge, p 26-38

Favero M, Khatchikian CE, Arias A, Silva-Rodriguez MP, Mariano-Jelicich R (2003) Estimates of seabird by-catch along the Patagonian Shelf by Argentine longline fishing vessels, 1999-2001. Bird Conserv Int 13:273-281

Fordham RA (1970) Mortality and population change of Dominican gulls in Wellington, New Zealand. J Anim Ecol 39:13-27

Furness RW (2003) Impacts of fisheries on seabird communities. Sci Mar 67(Suppl 2):33-45

Furness RW, Monaghan P (1987) Seabird ecology. Blackie, Glasgow

Furness RW, Ensor K, Hudson AV (1992) The use of fishery waste by gull populations around the British Isles. Ardea 80:105-113

Gandini P, Frere E, Pettovello AD, Cedrola PV (1999) Interaction between Magellanic penguins and shrimp fisheries in Patagonia, Argentina. Condor 101:783-789

Garthe S, Hüppop O (1994) Distribution of ship-following seabirds and their utilization of discards in the North Sea in summer. Mar Ecol Prog Ser 106:1-9

Giaccardi M, Yorio P (2004) Temporal patterns of abundance and waste use by kelp gulls at an urban and fishery waste tip in northern coastal Patagonia, Argentina. Ornitol Neotrop 15:93-102

Hudson AV, Furness RW (1989) The behaviour of seabirds foraging at fishing boats around Shetland. Ibis 131:225-237

Huin N (2001) Census of the blackbrowed albatross population of the Falkland Islands. Falklands Conservation, Stanley

Jones LL, DeGange R (1988) Interactions between seabirds and fisheries in the North Pacific Ocean. In: Burger J (ed) Seabirds' and other marine vertebrates' competition, predation and other interactions. Columbia University Press, New York, p 269-291

Klaer N, Polacheck T (1995) Japanese longline seabird bycatch in the Australian fishing zone: April 1991-March 1994. CSIRO, Hobart
Montevecchi WA (2002) Interactions between fisheries and seabirds. In: Schreiber EA, Burger J (eds) Biology of marine birds. CRC Press, Washington, DC, p 527-555

Oro D, Ruiz X (1997) Exploitation of trawler discards by breeding seabirds in the north-western Mediterranean: differences between the Ebro Delta and the Balearic Islands areas. ICES J Mar Sci 54:695-707

Oro D, Bosch M, Ruiz X (1995) Effects of a trawler moratorium on the breeding success of the yellow-legged gull Larus cachinnans. Ibis 137:547-549

Petyt C (1995) Behaviour of seabirds around fishing trawlers in New Zealand subantarctic waters. Notornis 42:99-115

Pierotti R, Annett C (1991) Diet choice in the herring gull: effects of constraints imposed by reproduction and ecology. Ecology 72:319-328

Robertson G, Gales R (1998) Albatross biology and conservation. Surrey Beatty, Chipping Norton

Ryan PG, Moloney CL (1988) Effect of trawling on bird and seal distributions in the southern Benguela region. Mar Ecol Prog Ser 45:1-11

Sullivan B (2004) Falkland Island plan of action for reducing incidental catch of seabirds in trawl fisheries. Falklands Conservation, Stanley

Sullivan B, Reid T (2002) Seabird interactions/mortality with longliners and trawlers in Falkland Island waters 2001/02. Falklands Conservation, Stanley

Tamini LL, Perez JE, Chiaramonte GE, Cappozzo HL (2002) Magellanic penguin (Spheniscus magellanicus) and fish as bycatch in the cornalito (Sorgentinia incisa) fishery at Puerto Quequén, Argentina. Atl Seabirds 4(3):109-114

Tasker M, Camphuysen CJ, Cooper J, Garthe S, Montevecchi WA, Blaver SJM (2000) The impacts of fishing on marine birds. ICES J Mar Sci 57:531-547

Thompson KR, Riddy MD (1995) Utilization of offal and discards from 'finfish' trawlers around the Falkland Islands by black-browed albatross Diomedea melanophris. Ibis 137:198-206

Wahl TR, Heinemann D (1979) Seabirds and fishing vessels: co-occurrence and attraction. Condor 81:390-396

Weichler T, Garthe S, Luna-Jorquera G, Moraga J (2004) Seabird distribution on the Humboldt Current in northern Chile in relation to hydrography, productivity, and fisheries. ICES J Mar Sci 61:148-154

Weimerskirch H, Brothers N, Jouventin P (1997) Population dynamics of wandering albatross Diomedea exulans and Amsterdam albatross $D$. amsterdamensis in the Indian Ocean and their relationships with long-line fisheries: conservation implications. Biol Conserv 79:257-270

Weimerskirch H, Capdeville D, Duhamel G (2000) Factors affecting the number and mortality of seabirds attending trawlers and longliners in the Kerguelen area. Polar Biol 23:236-249

Yorio P, Caille G (1999) Seabird interactions with coastal fisheries in northern Patagonia: use of discards and incidental captures in nets. Waterbirds 22:207-216

Yorio P, Caille G (2004) Fish waste as an alternative resource for gulls along the Patagonian coast: availability, use, and potential consequences. Mar Pollut Bull 48:778-783

Yorio P, Bertellotti M, Gandini P, Frere E (1998a) Kelp gulls (Larus dominicanus) breeding on the Argentine coast: population status and relationship with coastal management and conservation. Mar Ornithol 26:11-18

Yorio P, Frere E, Gandini P, Harris G (1998b) Atlas de la distribución reproductiva de Aves Marinas en el litoral patagónico argentino. Fundación Patagonia Natural and Wildlife Conservation Society, Puerto Madryn

Zar JH (1999) Biostatistical analysis. Prentice Hall, London 